\title{
Smear Specimen
}

National Cancer Institute

\section{Source}

National Cancer Institute. Smear Specimen. NCI Thesaurus. Code C85501.

A specimen prepared by spreading a thin layer of tissue across the surface of a slide. 